\title{
E-Learning's “De Facto” Implementation Probabilities in Educational Sector: A Preliminary Estimation if Confinement Should Be Extended in Covid-19 Crisis
}

\section{Context}

\author{
Semliko Fulbert DOSSOU (Corresponding author) \\ Institute of Social Sciences, Gazi University, Faculty of Economics and Administrative \\ Sciences, Department of Business Administration, Ankara, Turkey. \\ PO Box: Umut Mahallesi, Şehit Gazi Sok. 21/9 Ankara, Türkiye \\ E-mail: semliko.fd97@yahoo.com; semliko.dossou@hbv.edu.tr
}

Received: May 2, 2020 Accepted: July 7, 2020 Online published: August 10, 2020

doi:10.5296/jpag.v10i3.17509ＵRL: https://doi.org/10.5296/jpag.v10i3.17509

\begin{abstract}
Background: Before the Covid-19 breakout, some debates' subjects were left hanging in the education area: the E-Learning integration. With the pandemic impact (making closed almost all schools in the same month), the debate gained again importance. Among the temporal Anti-Covid-19 measures adopted, was the replacement of classic education by distance-online education.

Purpose: This article attempted a preliminary estimate related to the probabilities of E-learning's "de facto" implementation in different countries groups of the world if the confinement should be extended in Covid-19 crisis context.

Methods/Approach: The probabilistic method was adopted to analyze 143 countries including (49 High income, 40 upper-middle-income, 33 lower-middle-income, and 21 low-income economies). The main variables (related to E-learning), collected from official sources in the Covid-19 period were: Access-to-electricity, Access-to-Internet, Access-to-Multimedia-Devices (Personal-Computer, Tablet and/or Smartphone).

Results: Results showed that the probabilities of E-learning's "de facto" implementation would be around 0.6502 in the world, 0.8731 in High-Incomes, 0.7075 in Upper-Middle-Incomes, 0.5272 in Lower-Middle-Incomes, and 0.2950 in Low-Income economies.
\end{abstract}


Originality/value: (1) In the past, "suddenly closing almost all schools in the world" would be inadmissible. Everyone can henceforth believe in that eventuality after the experience with Covid-19. In this context, this research shows the need to reconsider E-learning or at least, a new hybrid education model as a "plan B" for future times. Thanks to technological integration, online and traditional education could go hand in hand, even after the Covid-19. (2) This study reminds the importance of speeding up the resolution of certain thorny (pending) problems such as access to energy and the development of educational infrastructure in certain regions of the world. The quality, performance and success of the educational component depend on it.

Keywords: covid-19 crisis context, "De facto" implementation, education sector, e-learning, probabilities

\section{Introduction}

The continuous and permanent search for increased performance in the education area has led to the development of E-learning (Čonková, 2013). Many governments and states have gradually started to take an interest in integrating online learning into their education systems. However, before the outbreak of the global pandemic known as the novel coronavirus "COVID-19", the world was already witnessing pending debates in some countries, related to the acceptance of the advanced integration of E-learning.

With the spread of the pandemic, "March 2020" was a special month; among many disturbances recorded in normal life, feature the temporary closings of almost all schools in the world [from 6-governments on March 1, the number increased to around 185-countries at the end-of-March, so 1.6 billion (about 90\%) of the pupils and students concerned] (UNESCO, 2020). The short-term loss of learning, the reduction of the Human Development Index, and some loss in long-term economic opportunities are some of the drawbacks that prolonged school closings can cause.

Face to that situation many countries, whatever their level of development, were forced to resort to online learning (at different degrees and in various forms) in order to mitigate the issue of the harmful effects of the learning loss. With the support of the World Bank, the Ministries of National Education of many States have actively worked in urgency to implement devices and means for distance learning (in this period of crisis). There are many reasons (ranging from main to secondaries) that explain the reluctance of some states to accept the advanced integration of remote learning. However, given that a sudden closure of "traditional" school classes may henceforth be an eventuality, and given that the WHO fears a possible "deadly resurgence" of the pandemic if deconfinement is hastened (UN News, 2020), the state of situation aroused a research question: "What would be the probabilities of E-learning's "de facto" implementation in different countries groups of the world if the confinement should be extended in Covid-19 Crisis Context?". This paper aimed to attempt to provide elements of answers to this question.

The remainder of this paper was organized as follows: Section 2 dealt with the theoretical background covering some essential reminders about the E-Learning. In Section 3 the 
methodology was presented. Section 4 provided the results while section 5 dealt with some lessons learned from Covid-19 experience for the education sector, and finally, the conclusion was provided.

\section{Theoretical Background}

The development of technology and digitalization offered new educational systems and learning possibilities, including E-Learning.

\subsection{Definition and Typology of E-learning}

According to the European Commission (2001): "E-learning is the use of new multimedia technologies and the Internet to improve the quality of learning by facilitating, on the one hand, the access to resources and services, and on the other hand, the exchanges and collaboration at a distance". Allen and Seaman (2008) propose a typology whose criterion of distinction is based on the proportion of content posted online. These authors distinguish four forms of e-learning courses (Table 1).

Table 1. Typology of e-learning courses according to the content posted online

\begin{tabular}{ccc}
\hline $\begin{array}{c}\text { Proportion } \\
\text { provided online }\end{array}$ & Type of course & Description \\
\hline $0 \%$ & Face-to-face (traditional) courses & Course without any web technology \\
{$[1 \% ; 29 \%]$} & Web-based courses & Course using web technologies to facilitate learning \\
{$[30 \% ; 79 \%]$} & Hybrid courses (blended) & $\begin{array}{c}\text { Courses of which a significant part is given online } \\
\text { Most courses are taught online and typically have no } \\
\text { face-to-face meeting scheduled }\end{array}$ \\
\hline
\end{tabular}

Source: Allen and Seaman (2008)

Benraouane (2011), meanwhile, distinguished three types of courses:

(1) Synchronous online courses with trainer/teacher: These courses and interactivity are in real-time. The tools used are chat rooms and videoconferences.

(2) Asynchronous online courses without trainer/teacher: These courses aren't given in real-time and the teaching is often led by didactic software, in flexible time.

(3) Asynchronous online courses with trainer/teacher: Teaching is led by a teacher who designs and plans the educational activities, structures the learning, and then gives the learners a time to complete their teaching duties and tasks. Then it assesses their performance. The interactivity between students and teachers isn't in real-time but delayed. Learners thus form a virtual class cohort and advance in groups.

In the present work which is interested in the pedagogical framework, the understanding of e-learning more considers online courses with trainer/teacher.

\subsection{Advantages and Challenges in E-Learning Implementation}

The development of e-learning has certain advantages but its successful implementation 
presents some challenges, which can be grouped according to educational, organizational, or economic aspects (Hügi, 2014). This paper focuses on the educational aspect.

\subsubsection{Advantages}

E-learning provides:

(1) Accessibility to knowledge, multimedia resources, and educational software that exist on the Internet; large-scale knowledge sharing (Benraouane, 2011);

(2) Flexibility: Learners can follow a training program according to the pace, place, time of their convenience;

(3) Adaptability to specific needs and context, individualization of the training course, and autonomy in training management;

(4) Deployment: Worldwide distribution without geographic barriers, and locally, the State can meet the educational needs of populations living far from urban centers;

(5) Reduction and control of training costs: (elimination of some expenses required by face-to-face classroom teaching, and an e-learning program can reach a larger number of participants);

(6) Optimized time management: (easy and fast) development, improvement, deepening and updating of knowledge thanks to digital resources; quick research and reviews of key parties thanks to the navigation system of technologies;

(7) More interactivity and involvement: the manipulation of learning resources (multimedia peripherals, web pages, files, and other software related to the learning activity), allows the learner to become active in learning and interactive with learning (Benraouane, 2011);

(8) Development of digital skills through [(1) the use of multimedia peripherals, word processing, data tables, information storage, and management; (2) understanding the risks and opportunities on the internet, and (3) communication via electronic media, information exchange, networking, learning, and research];

(9) More efficiency in training management.

Besides, in terms of pedagogical added value, e-learning facilitates the diversification of teaching methods and learning methods, which makes it possible to respond to the different cognitive styles present in learners. Thus, according to AWT (2008), an online course allows the alternation between visual, sound, textual supports, etc., which positively influences students' motivation. E-learning also stimulates greater interactivity between the learners and the educational content. That increased interactivity leads to greater involvement and receptiveness of the students (Saleh, 2004). An e-learning program allows the trainer to manage and control who receives the training, when, how many times and in what order; this facilitates personalized and individual monitoring of the learner. 


\subsubsection{Challenges in E-Learning Successful Implementation}

Many authors have already conducted studies on this aspect. According to them, E-learning requires:

(1) Accessibility to electricity, Internet, and to a multimedia device (computer, tablet, and/or smartphone); if the operating cost seems cheaper and affordable, the investment cost (infrastructure, equipment, platform, and bandwidth) seems to be high in certain places to the point of demotivating the interested parties;

(2) Reliability and speed maintenance service for devices (Tudor, 2008);

(3) Basic technological and digital skills for using multimedia devices and browsing on the Internet in the pedagogical framework (Benraouane, 2011);

(4) The creation of an interactive device and taking advantage of multimedia possibilities to create added value (Tudor, 2008);

(5) Identification of learners' needs and expectations (Bissey, 2003) to adapt the educational content accordingly (Benraouane, 2011);

(6) Availability of support services and educational resources on the Internet as well as online learning platforms for teachers, students, and parents;

(7) Educational monitoring (Bellier, 2001; Bissey, 2003; Tudor, 2008; Prat, 2010);

(8) For learners, more effort and motivation in e-learning than face-to-face (Tudor, 2008); otherwise, the dropout rate could be high, because of learner's isolation and feeling of loneliness, after a lack of human contact (Bellier, 2001; Saleh, 2004); especially if there isn't accompaniment planned (Prat, 2010);

(9) A great autonomy, a certain degree of self-discipline (Saleh, 2004), and a metacognition skill (knowing how to learn most effectively) (Bissey, 2003).

\subsection{Theoretical Foundations of E-Learning: the Educational Constructivism}

As e-learning is continuing its experimental phase in certain countries, there is a lack of unanimous theoretical foundations from researchers. However, during the few years that have witnessed the emergence of this system, the philosophical current to which it belongs has been identified. Bangert (2004) and Dede (2006) are among the authors who claim that e-learning is a form of education that fits into the mainstream of educational constructivism. According to this current, the primary purpose of learning, and education in general, is to help the learner to build himself, his knowledge (Benraouane, 2011). The design of the educational activity must take into account the concrete reality of the learner. Unlike the classical approach to teaching which considers the learner as the object that undergoes knowledge, the constructivist approach rather considers him as the subject who creates himself, his knowledge. In this philosophical conception, the pedagogy of "making someone learn" must be centered on the individual who learns (learner-centered pedagogy) and not on the individual who teaches (teacher-centered pedagogy). 


\section{Methodology}

As announced at the beginning, this paper focuses on "an estimate of the implementation" de facto ", rather than on" an estimate of the effective implementation of E-learning "; the last aspect should constitute another subject extensive research. Besides, "de facto" is a Latin expression which means "in fact", as opposed to "de jure" which means "in-law" or "as of right". The probabilistic method (simple random sampling) was adopted since the list of all the countries with their main data were available. This method has the advantage of a very high generalization of the results because the sample is representative. The constitution of the sample for this study was based on data availability and took into account 143 countries (approximately $65.60 \%$ of the global countries' number). These countries dispersed in geographic areas and spread over different continents were selected according to the classification of the World Bank (2019), based on income levels. Table 2 gives a detail about the composition of the sample.

Table 2. Size and composition of the study sample

\begin{tabular}{ccccc}
\hline $\begin{array}{c}\text { Classification by } \\
\text { Income level }\end{array}$ & Classification Criterion & $\begin{array}{c}\text { Total number } \\
\text { in the World }\end{array}$ & $\begin{array}{c}\text { Sample } \\
\text { Size }\end{array}$ & Percentage \\
\hline $\begin{array}{c}\text { High-Income Economies } \\
\text { Upper-Middle Income } \\
\text { Economies }\end{array}$ & GNI per capita $(\$ 12,376$ or more $)$ & 80 & 49 & $61.25 \%$ \\
Lower-Middle Income & GNI per capita $(\$ 3,996$ to $\$ 12,375)$ & 60 & 40 & $66.67 \%$ \\
Economies & GNI per capita $(\$ 1,026$ to $\$ 3,995)$ & 47 & 33 & $70.21 \%$ \\
Low-Income Economies & GNI per capita $(\$ 1,025$ or less $)$ & 31 & 21 & $67.74 \%$ \\
Total & & 218 & 143 & $65.60 \%$ \\
\hline
\end{tabular}

Source: Author's compilations, based on World Bank classification (2019)

The estimates are based on data and indicators (related to E-learning) collected from official sources, and dating from the Covid-19 period.

The logic is based on the following assumptions:

(1) The impact of the Covid-19 and its threat constitutes a factor stimulating the acceptance, and adaptation to E-learning;

(2) The increasing practice and habit of (individuals, organizations, and States), to networks and social media for several years, constitutes an asset to their digital culture development;

(3) Social media platforms and applications usable in an educational context like (Skype, Zoom Cloud Meeting, etc.) are accessible and free to download, so that the main variables retained integrate the "sine qua non" conditions for E-learning "de facto" implementation.

The variables used are described as follows:

Access to electricity: the average rate of the population having access to electricity in a given country; 


\section{Macrothink}

Journal of Public Administration and Governance

ISSN 2161-7104

2020, Vol. 10, No. 3

Access to the Internet: the average rate of the population having access to the internet from a given country;

Access to a Multimedia Device: the average rate of the population that owns at least a Multimedia Device in a given country. This last variable was distinguished in 2 groups: [(a) Personal Computer users; (b) Tablet, Smartphone, and/or PDA: Personal Digital Assistant users].

In addition, some other moderation variables (relating to the human factor and the use of technology for educational purposes) were also taken into consideration.

A conceptual model including the variables used is presented in Figure 1.

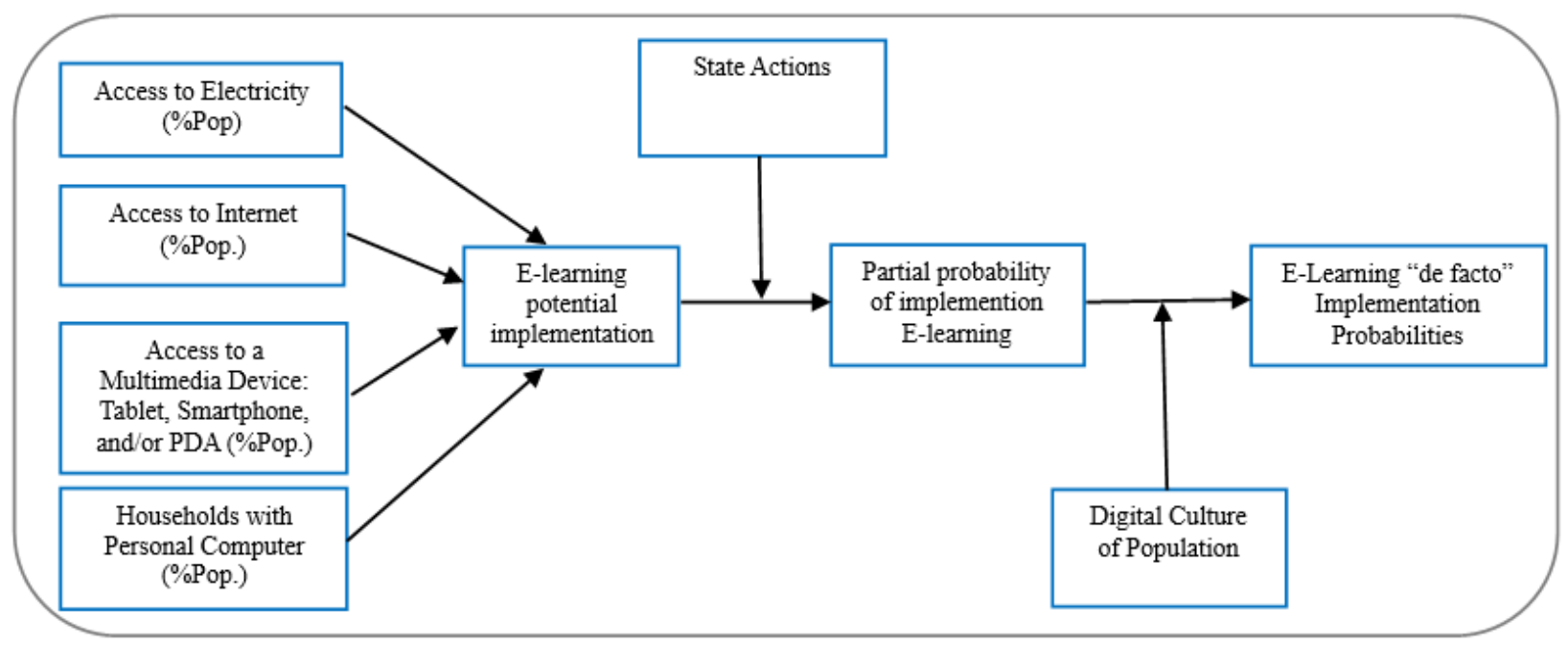

Figure 1. Conceptual model

Source: Author's proposal

If $\mathrm{x}$ is considered as the random variable giving the indicators (relating to E-learning) in a given country, its mathematical expected value can be calculated from the probability law of $\mathrm{x}$ by the following formula:

$$
\mathrm{E}(x)=\sum_{i=1}^{k} x_{i} \cdot p\left(x_{i}\right)
$$

And for a given group of economies the general formula could be written as follows:

$$
\Pi(\mathrm{X} ; g)=\sum_{i=1}^{k} \cdot \sum_{j=1}^{n} \mathrm{X}_{i j} \mathbf{P}(\mathrm{X})_{i j}
$$

Where:

$\Pi$ : represents the mathematical expectation of the global probability of E-learning's "de facto" implementation for a given group of economies

$\mathrm{X}$ : represents a matrix of the mathematical expected values of the indicators related to E-learning implementation 
$\mathrm{P}(\mathrm{X})$ : represents the matrix of associated probabilities

g: designates a given group of economies in which a set of classified countries appears (example: High Income Economies)

$x_{i}$ : denotes an indicator variable and $\mathrm{k}$, the number of variables

$j$ : denotes a country and $\mathrm{n}$, the sample size for a given group of economies.

\section{Results}

Findings are focused on the results relating to the group of economies instead of individual countries. The preliminary estimates that if during 2020 in the Covid-19 crisis context, containment should be extended for months in almost all the countries in the world, and taking into account the sine qua non required conditions, the overall probability (of E-learning's "de facto" implementation) would be 0.6502 as the worldwide average. In general, due to the current pandemic circumstances that constitute a major stake, the share of the population more and more interested in E-learning, and the number of States and schools which are experimenting its implementation is growing continuously. However, the behavior of the variables in terms of statistical dispersion varies from one group of countries to another. Besides, it is obvious that the closer you get to developing countries, the more the gravity center of these values which was initially higher than the global average (in developed countries), migrates towards lower values (Figure 2).
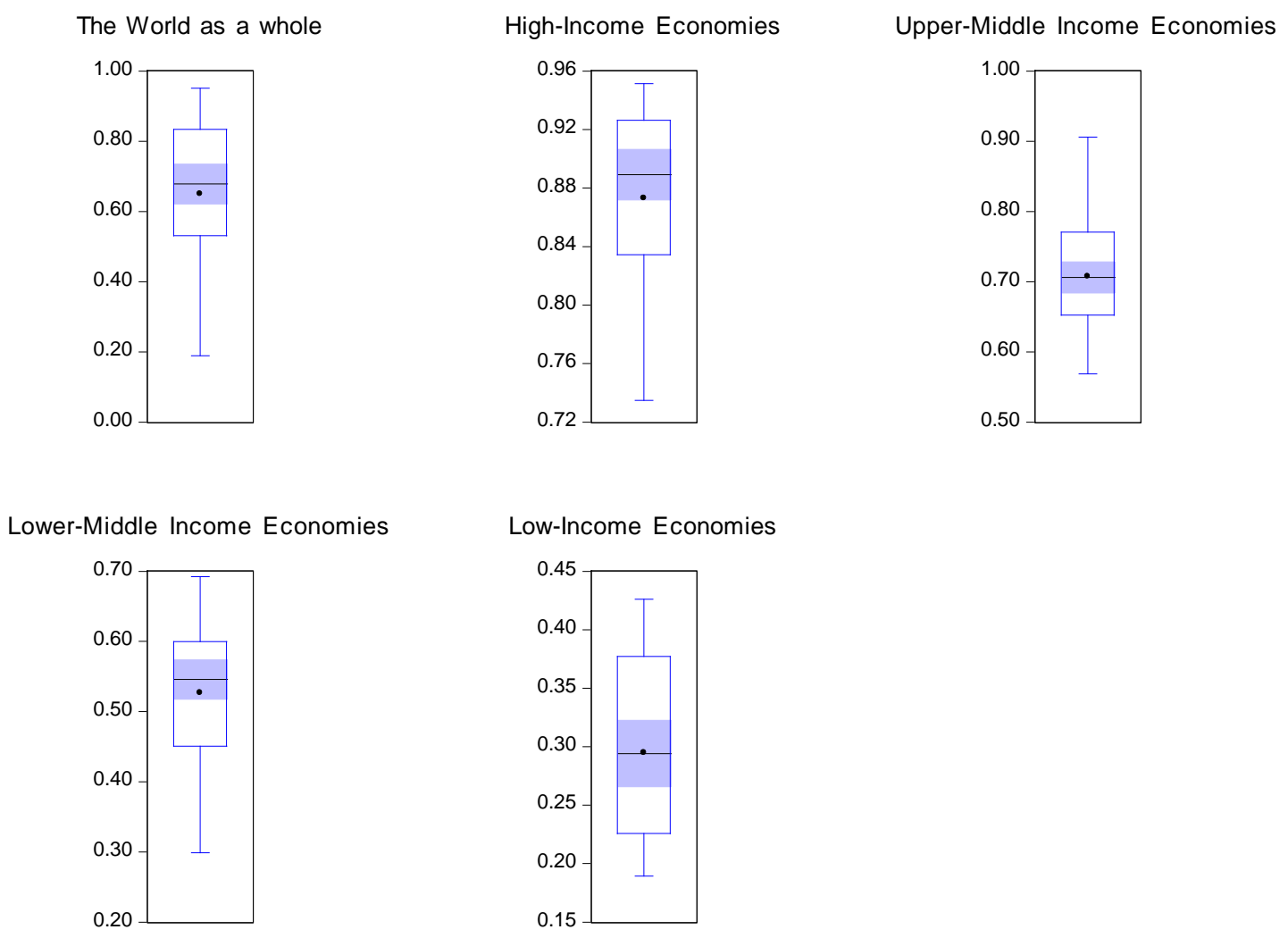

Figure 2. Graphical Illustration of Estimated Probabilities 
Source: Author's estimations

According to the estimations, the probabilities would be around 0.8731 in High-Incomes, 0.7075 in Upper-Middle-Incomes, 0.5272 in Lower-Middle-Incomes, and 0.2950 in Low-Income economies (Tables 3 and 4). These results corroborate those of Brookings (2020), who estimated that currently, almost $90 \%$ of high-income countries adopt distance education (almost all online), while in low-income countries, this rate hovers around $25 \%$ (with television and radio as additional support resources).

Table 3. Synthesis of results

\begin{tabular}{|c|c|c|c|c|c|c|c|}
\hline \multirow{2}{*}{$\begin{array}{l}\text { Group of } \\
\text { Economies }\end{array}$} & \multirow{2}{*}{ Variables } & \multirow{2}{*}{ Mean } & \multirow{2}{*}{$\begin{array}{l}\text { Std. } \\
\text { Dev. }\end{array}$} & \multirow{2}{*}{$\begin{array}{c}\text { Potential } \\
\text { Impl. } \\
\text { Empirical } \\
\text { Mean (\%) }\end{array}$} & \multicolumn{2}{|c|}{$\begin{array}{c}\text { Moderation } \\
\text { variables }\end{array}$} & \multirow{2}{*}{$\begin{array}{r}\text { Proba- } \\
\text { bility }\end{array}$} \\
\hline & & & & & $\begin{array}{l}\text { State } \\
\text { Act }^{\circ}\end{array}$ & $\begin{array}{l}\text { Digital } \\
\text { Culture }\end{array}$ & \\
\hline \multirow{5}{*}{$\begin{array}{l}\text { The World } \\
\text { as a whole }\end{array}$} & ACCESS_TO_ELECTRICITY (\%Pop.) & 89.2892 & 21.3562 & \multirow{4}{*}{64.5018} & \multirow{4}{*}{0.2185} & \multirow{4}{*}{0.4370} & \multirow{4}{*}{0.65021} \\
\hline & ACCESS_TO_INTERNET (\%Pop.) & 68.2769 & 24.9232 & & & & \\
\hline & TABLET/PDA/SMARTPH_USERS (\%Pop.) & 69.9938 & 21.0727 & & & & \\
\hline & HOUSEHOLDS_WITH_PC (\%Pop.) & 56.4470 & 29.0372 & & & & \\
\hline & Observations (Number of Countries) & 143 & 143 & 143 & 143 & 143 & 143 \\
\hline \multirow{5}{*}{$\begin{array}{c}\text { High- } \\
\text { Income } \\
\text { Economies }\end{array}$} & ACCESS_TO_ELECTRICITY (\%Pop.) & 100 & 0 & \multirow{4}{*}{86.2952} & \multirow{4}{*}{0.2944} & \multirow{4}{*}{0.5889} & \multirow{4}{*}{0.87312} \\
\hline & ACCESS_TO_INTERNET (\%Pop.) & 87.2180 & 12.1135 & & & & \\
\hline & TABLET/PDA/SMARTPH_USERS (\%Pop.) & 88.0046 & 8.3280 & & & & \\
\hline & HOUSEHOLDS_WITH_PC (\%Pop.) & 81.9584 & 11.6722 & & & & \\
\hline & Observations & 49 & 49 & 49 & 49 & 49 & 49 \\
\hline \multirow{5}{*}{$\begin{array}{c}\text { Upper- } \\
\text { Middle } \\
\text { Income } \\
\text { Economies }\end{array}$} & ACCESS_TO_ELECTRICITY (\%Pop.) & 96.4375 & 9.9628 & \multirow{4}{*}{67.2507} & \multirow{4}{*}{0.2476} & \multirow{4}{*}{0.4951} & \multirow{4}{*}{0.70760} \\
\hline & ACCESS_TO_INTERNET (\%Pop.) & 68.185 & 17.3046 & & & & \\
\hline & TABLET/PDA/SMARTPH_USERS (\%Pop.) & 80.745 & 11.7440 & & & & \\
\hline & HOUSEHOLDS_WITH_PC (\%Pop.) & 51.1145 & 18.1982 & & & & \\
\hline & Observations & 40 & 40 & 40 & 40 & 40 & 40 \\
\hline \multirow{5}{*}{$\begin{array}{l}\text { Lower- } \\
\text { Middle } \\
\text { Income } \\
\text { Economies }\end{array}$} & ACCESS_TO_ELECTRICITY (\%Pop.) & 82.4546 & 20.5386 & \multirow{4}{*}{52.5077} & \multirow{4}{*}{0.1764} & \multirow{4}{*}{0.3528} & \multirow{4}{*}{0.52715} \\
\hline & ACCESS_TO_INTERNET (\%Pop.) & 55.9467 & 18.3995 & & & & \\
\hline & TABLET/PDA/SMARTPH_USERS (\%Pop.) & 69.8030 & 9.7821 & & & & \\
\hline & HOUSEHOLDS_WITH_PC (\%Pop.) & 30.5527 & 15.0424 & & & & \\
\hline & Observations & 33 & 33 & 33 & 33 & 33 & 33 \\
\hline & ACCESS_TO_ELECTRICITY (\%Pop.) & 44.6810 & 26.4890 & \multirow{4}{*}{27.7845} & \multirow{4}{*}{0.1040} & \multirow{4}{*}{0.2079} & \\
\hline Low- & ACCESS_TO_INTERNET (\%Pop.) & 31.8910 & 18.5419 & & & & \\
\hline Income & TABLET/PDA/SMARTPH_USERS (\%Pop.) & 39.3 & 5.7254 & & & & 0.29498 \\
\hline \multirow[t]{2}{*}{ Economies } & HOUSEHOLDS_WITH_PC (\%Pop.) & 14.6381 & 2.8479 & & & & \\
\hline & Observations & 21 & 21 & 21 & 21 & 21 & 21 \\
\hline
\end{tabular}

Source: Author's estimations, based on data from the World Bank (2019), Bankmycell (2020), Internet World Stats (2020), and (Statista, 2020) 
Table 4. Synthesis of results (suite)

\begin{tabular}{ccccccc}
\hline $\begin{array}{c}\text { Group of } \\
\text { Economies }\end{array}$ & $\begin{array}{c}\text { Estimated } \\
\text { Probability }\end{array}$ & $\begin{array}{c}\text { Confidence } \\
\text { Level }(\mathbf{9 5 . 0 \%})\end{array}$ & $\begin{array}{c}\text { Confidence } \\
\text { Interval }\end{array}$ & Std. Dev. & Skewness & Kurtosis \\
\hline $\begin{array}{c}\text { The World as a } \\
\text { whole }\end{array}$ & $\mathbf{0 . 6 5 0 2 1 4}$ & 0.053185 & {$[0.5970 ; 0.7034]$} & 0.223053 & -0.5453 & -0.7543 \\
$\begin{array}{c}\text { High-Income } \\
\text { Economies }\end{array}$ & $\mathbf{0 . 8 7 3 1 1 7}$ & 0.0286037 & {$[0.8445 ; 0.9017]$} & 0.064514 & -0.7682 & -0.3253 \\
$\begin{array}{c}\text { Upper-Middle } \\
\text { Income Economies } \\
\text { Lower-Middle }\end{array}$ & $\mathbf{0 . 7 0 7 5 9 2}$ & 0.041771 & {$[0.6658 ; 0.7494]$} & 0.091766 & 0.1537 & -0.5045 \\
$\begin{array}{c}\text { Income Economies } \\
\text { Low-Income }\end{array}$ & $\mathbf{0 . 5 2 7 1 4 8}$ & 0.063965 & {$[0.4632 ; 0.5911]$} & 0.115507 & -0.6909 & -0.6190 \\
Economies & $\mathbf{0 . 2 9 4 9 8 1}$ & 0.056391 & {$[0.2386 ; 0.3514]$} & 0.088752 & 0.1875 & -1.5979 \\
\hline
\end{tabular}

Source: Author's estimations

Although E-Learning seems not yet fully accepted by all, it's considered as a system complementary to the overall action plan in the field of education, which is revolutionizing and improving pedagogy, teaching techniques, and materials (European Commission, 2001). This system has some limits in certain types of training, however, as shown in Allen \& Seaman (2008), Vargas \& Tian (2013), and Couette (2019), online training rates especially in developed countries is growing strongly. In low-income economies, the situation is critical and calls for reflection, insofar as the question of infrastructures and "sine qua non" conditions required for 'de facto' implementation of the E-learning system, are still far from to be resolved. This situation constitutes indeed one of the fundamental reasons for the reluctance of some countries to fully approve the E-learning system in their geographic area.

\section{Some Lessons Learnt From the Covid-19 Experience for the Education Area}

The accelerated pace to which schools were closed during March 2020 in all the world, was unprecedented in history. The consequences of Covid-19 will certainly vary from an area to another; however in this article, at the current stage of the situation, some lessons (both positive and negative aspects) learned from this experience for the education field can already be mentioned.

\subsection{Some Positive Aspects of Lessons Learnt}

1) In the past, "Suddenly closing almost all schools worldwide" would be inadmissible. Everyone can henceforth believe in that eventuality after the experience of Covid-19. The drawbacks resulting from the constraint of hasty implementation of distance education, lead to reorganize the education systems as a whole, to reinforce, and to renovate it, according to the weaknesses revealed.

2) Effective or not, distance education was implemented and experienced more influx. It could be admitted as a "B plan" for future times. And, as some have already argued, that led 
certain governments to reconsider their positions on the approval of a hybrid approach of the education system (classic face-to-face \& virtual at distance).

3) The acquisition of knowledge and skills at a global level is experiencing a rebound forward. Indeed, technology facilitated the acceleration of knowledge sharing and practices and increased the collaboration between teachers, academic members, and researchers around the world through networking.

4) By sharing information and educating in schools, learners (in particular children from a very young age) are already receiving a sort of training on some individual and collective hygienic measures (in public health), to be adopted in the event of an epidemic. This will greatly help to control the spread of certain epidemic infections similar to COVID-19 in the future.

5) On an individual level, Covid-19 led students to develop a digital culture in the educational context and to improve their level of autonomy, metacognition, and self-discipline.

6) The Covid-19 crisis reminded the importance of speeding up the resolution of certain thorny problems such as access to drinking water, energy, and the development of educational infrastructure in certain regions of the world. The quality, performance, and success of the educational component also depend on it.

7) The opportunity has come for the leaders of these regions to rethink differently, to take advantage of the natural resources available in their regions to reduce certain inequalities in terms of education and poverty line in general.

\subsection{Some Negative Aspects of Lessons Learnt}

1) Due to the lack of training in new educational methods with technology use, and a lack of adequate infrastructures (in some areas), the unexpected and rapid transition from classic education to online education could result in poor user experience with weak sustainable satisfaction. So, with the eventualities of poor academic performance, criticism against distance education could take a bad turn and be intensified.

2) The monitoring and control that could have been exerted by teachers in face-to-face classic education ambiance disappeared, which has in return an impact on the efficiency level in terms of learners' knowledge acquisition.

3) An even more delicate situation, especially since teachers and educators (as humans) initially unprepared for such an eventuality are themselves struck by this crisis, hence the impact on the effectiveness of their work.

4) In some families, tension increased between certain parents and their children (for having replaced the teacher and tried to closely follow or control the behavior of their children in terms of studies).

5) While access to energy, internet, and basic (essential) technologies is fully guaranteed and exploited to boost knowledge and skills in advanced countries, these necessities are still difficult to access in certain low-income regions. For the learners of those regions, even if the 
willingness or wish (to work hard for higher degree studies) is an objective, the factors listed constitute serious handicaps, thus hampering access to high-quality education..

\section{Conclusion}

The aim of this article was to attempt a preliminary estimate related to the probabilities of E-learning's "de facto" implementation in different countries groups of the world if the confinement should be extended in Covid-19 Crisis Context. For that, the probabilistic method was adopted, and the analysis took into account 143 countries including (49 High income, 40 upper-middle-income, 33 lower-middle-income, and 21 low-income economies). The main variables (related to E-learning), collected from official sources in Covid-19 period were: Access to electricity, Access to Internet, Access to Multimedia Devices (Personal-Computer, Tablet, PDA, and/or Smartphone). Besides, some other moderation variables were also taken into consideration.

The Results showed that the probabilities of E-learning's "de facto" implementation would approximately be 0.6502 for the worldwide, 0.8731 in High-Incomes, 0.7075 in Upper-Middle-Incomes, 0.5272 in Lower-Middle-Incomes, and 0.2950 in Low-Income economies. The gaps are evident and striking in terms of the probable implementation rates, and so that, advantages and disadvantages of E-learning could differently be perceived (due to persistent disparities) in terms of conditions and realities depending on the level of development of the countries. This explains the reluctance of some countries to fully accept the E-learning system.

Long before the advent of Covid-19, schools, universities, institutions, and business entities around the world were already offering thousands of online courses, including training and higher education with certification, to meet effective and efficient training needs. Rather, studies and data covering the current decade show growing trends in online training rates, especially in developed countries (Allen \& Seaman, 2008; Vargas \& Tian, 2013, and Couette 2019). Online training is undoubtedly a revolution in education and knowledge transfer. According to Couette (2019), learning is $17 \%$ more effective online than in the classroom. Thanks to its flexibility, diversity, and interactivity, this process would provide better satisfaction for the student and better financial results for the teacher. This observation also seems evident in both the academic, professional, and business communities. This confirms the forecasts that the rate of integration of E-learning isn't ready to decline so soon.

Discussion: What perspectives for the future of education?

With the Covid-19 experience, in some countries where the effectiveness of distance education has begun to show its limits, the return to classic face-to-face education is more and more desired. In fact, (1) some believe that due to the lack of training in new educational methods with technology use, and a lack of adequate infrastructures in some places, the unexpected and rapid transition from classic education to online education would result in poor user experience with weak sustainable satisfaction. Others rather think of the emergence of a new hybrid education model, with significant advantages, thanks to the technology integration in the education sector, which will accelerate and make online education an integral part of education. And so, even after coronavirus, online and classic education could go hand in hand (Apolitical, 2020). 
Limits of the study and perspectives for further research: Certain specific data weren't accessible during the research period. This forced the present study to be limited to only the preliminary estimation of the probabilities related to "de facto" implementation of E-learning. It's clear that (1) "de facto" implementation of E-learning and (2) the "effectiveness" of E-learning implementation constitute two distinct research subjects. So, even outside the Covid-19 context, it would be interesting to conduct in further researches, advanced analyzes on "'the effectiveness of E-learning"; and take into account some additional factors.

\section{References}

Allen, E., \& Seaman, J. (2008). Staying the Course: Online Education in the United States,. Newburyport, MA. Sloan Consortium.

Apolitical. (2020, May 5). COVID-19 a changé l'éducation pour toujours - voici un commentaire,. Retrieved May 22, 2020, from https://apolitical.co/home: https://apolitical.co/fr/solution_article/covid-19-a-change-1-education-pour-toujours-comment AWT. (2008). Guide de l'e-learning. In : awt.be [en ligne]. Jambes : Agence Wallonne des Télécommunications.

Bangert, A. (2004). The seven principles of good practice: A framework for evaluating en ligne teaching. The internet and higher education, 7(3), 217-232. https://doi.org/10.1016/j.iheduc.2004.06.003

Bankmycell. (2020). Bankmycell: HOW MANY SMARTPHONES ARE IN THE WORLD. Retrieved May 2020, from https://www.bankmycell.com/: https://www.bankmycell.com/blog/how-many-phones-are-in-the-world

Bellier, S. (2001). Le e-learning. Rueil-Malmaison : Ed. Liaisons. Entreprise et carrières. ISBN 2878803671.

Benraouane, S. (2011). Guide pratique $d u$ e-Learning,. Dunod, Paris, ISBN 978-2-10-056233-6.

Bissey, C. (2003). TIC et Net: nouvelles voies pour la formation. Paris : Presses universitaires de France. Education et formation. ISBN 2130538223.

Brookings. (2020, April 14). REPORT: School closures, government responses, and learning inequality around the world during COVID-19,. Retrieved April 28, 2020, from https://www.brookings.edu/research/:

https://www.brookings.edu/research/school-closures-government-responses-and-learning-ine quality-around-the-world-during-covid-19/

Commission, E. (2001, March 28). Plan D'action Elearning - Penser L'éducation De Demain,. Communication De La Commission Au Conseil Et Au Parlement Europeen, Bruxelles, le 28.3.2001, $\operatorname{COM}(2001) 172$ final, pp. https://ec.europa.eu/transparency/regdoc/rep/1/2001/FR/1-2001-172-FR-F1-1.Pdf .

Čonková, M. (2013, December). Analysis of Perceptions of Conventional and E-Learning 


\section{Macrothink}

Journal of Public Administration and Governance ISSN 2161-7104 2020, Vol. 10, No. 3

Education in Corporate Training. Journal of Competitiveness, 5(4), 73-97. https://doi.org/10.7441/joc.2013.04.05

Couette, M.-H. (2019, August 19). "Le marché de la formation en ligne est en forte croissance". Retrieved May 25, 2020, from Didacte: https://www.didacte.com/fr/articles/le-marche-de-la-formation-en-ligne-est-en-forte-croissanc e

Dede, C. (2006). Online professional development for teachers: Emerging models and methods. Harvard Education Publishing Group.

Hügi, J. (2014). Développement d'une formation e-learning sur les Linked Open Data dans les bibliothèques,. Haute École de Gestion de Genève (HEG-GE),. Retrieved from https://core.ac.uk/download/pdf/43660151.pdf

Prat, M. (2010). E-learning: réussir un projet: pédagogie, méthodes et outils de conception, déploiement, évaluation. 2e éd. St Herblain : ENI. Objectif solutions. ISBN 9782746059498.

Saleh, I. (2004). Enseignement ouvert et à distance: épistémologie et usages. Paris : Hermès Science: Lavoisier. IC2: information, commande, communication. Management et gestion des STICS. ISBN 2746209357.

Tudor, H. (2008). All About E-Learning. In : AllAboutElearning.lu [en ligne]. Luxembourg : Centre de Recherche Public Henri Tudor.

UN News. (2020, May). Tedros highlights complex challenges posed by COVID-19 resurgence, as lockdowns ease. Retrieved May 24, 2020, from https://news.un.org: https://news.un.org/en/story/2020/05/1063732

UNESCO. (2020, April). COVID-19 Educational Disruption and Response,. Retrieved April 27, 2020, from https://en.unesco.org: https://en.unesco.org/covid19/educationresponse

Vargas, N., \& Tian, X. (2013). E-Learning: Much More than a Matter of Technology. International Journal of e-Education, e-Business, e-Management and e-Learning, 3(3), 277. https://doi.org/10.7763/IJEEEE.2013.V3.240

World-Bank. (2019). World Bank World Development Indicators Database (WDI). Washington D.C. World Bank.

\section{Copyright Disclaimer}

Copyright for this article is retained by the author(s), with first publication rights granted to the journal.

This is an open-access article distributed under the terms and conditions of the Creative Commons Attribution license (http://creativecommons.org/licenses/by/4.0/). 